\title{
ANALISIS PERBEDAAN REDUPLIKASI DIALEK RAHONG DAN DIALEK KOLANG DALAM BAHASA MANGGARAI PROVINSI NUSA TENGGARA TIMUR
}

\author{
Fransiskus Mariano Jer ${ }^{1}$, Ramdhan Mahmoed ${ }^{2}$, \\ Marhaendra Putra Hutama ${ }^{3}$ \\ Universitas Dr.Soetomo \\ ${ }^{1}$ masrinojer@gmail.com, ${ }^{2}$ ramdhan.mahmoed@gmail.com, \\ 3putra hutama@gmail.com
}

\begin{tabular}{ll}
\hline Informasi Artikel & \multicolumn{1}{c}{ ABSTRACT } \\
\hline Submit: $2-3-2020$ & Language style is the way that an author conveys his or her \\
Diterima: $10-4-2020$ & opinion using a language that is beautiful and harmonious \\
Dipublikasikan: $15-4-2020$ & and able to address meaning and atmosphere that can touch \\
& the intellectual power and emotion of the reader. The style \\
& of comparative language is this majas trying to reveal things \\
& by comparing sutu things or circumstances with a thing or \\
& other circumstance. According to other specialists \\
& comparing something to another, it is trying to find traits \\
& that show similarities between the two. Researchers \\
& determined two problems in the study, among others: 1) \\
& How the Association of Language of the corporation in a \\
& white Love Black book by Nabil Hamid Al-Ma'az?, and 2) \\
& How to style comparative personification in love books \\
& Black Love White by Nabil Hamid Al-Ma'az?. The research \\
& methodelogi used in this research is a qualitative design, \\
& this is because the data of research results is described by \\
& not prioritizing numeric figures, but prioritizing the depth of \\
the passion for interactions Which is being examined by & empirical researchers. The data analysis techniques used \\
are: 1) data reduction, 2) data presentation, 3) data \\
verification, and 4) data removal. From the results of this \\
study, were found three language style comparison data \\
personification, and five data style comparison association \\
languages. \\
Keywords: reduplication, rahong dialect, kolang dialect, \\
manggarai language
\end{tabular}




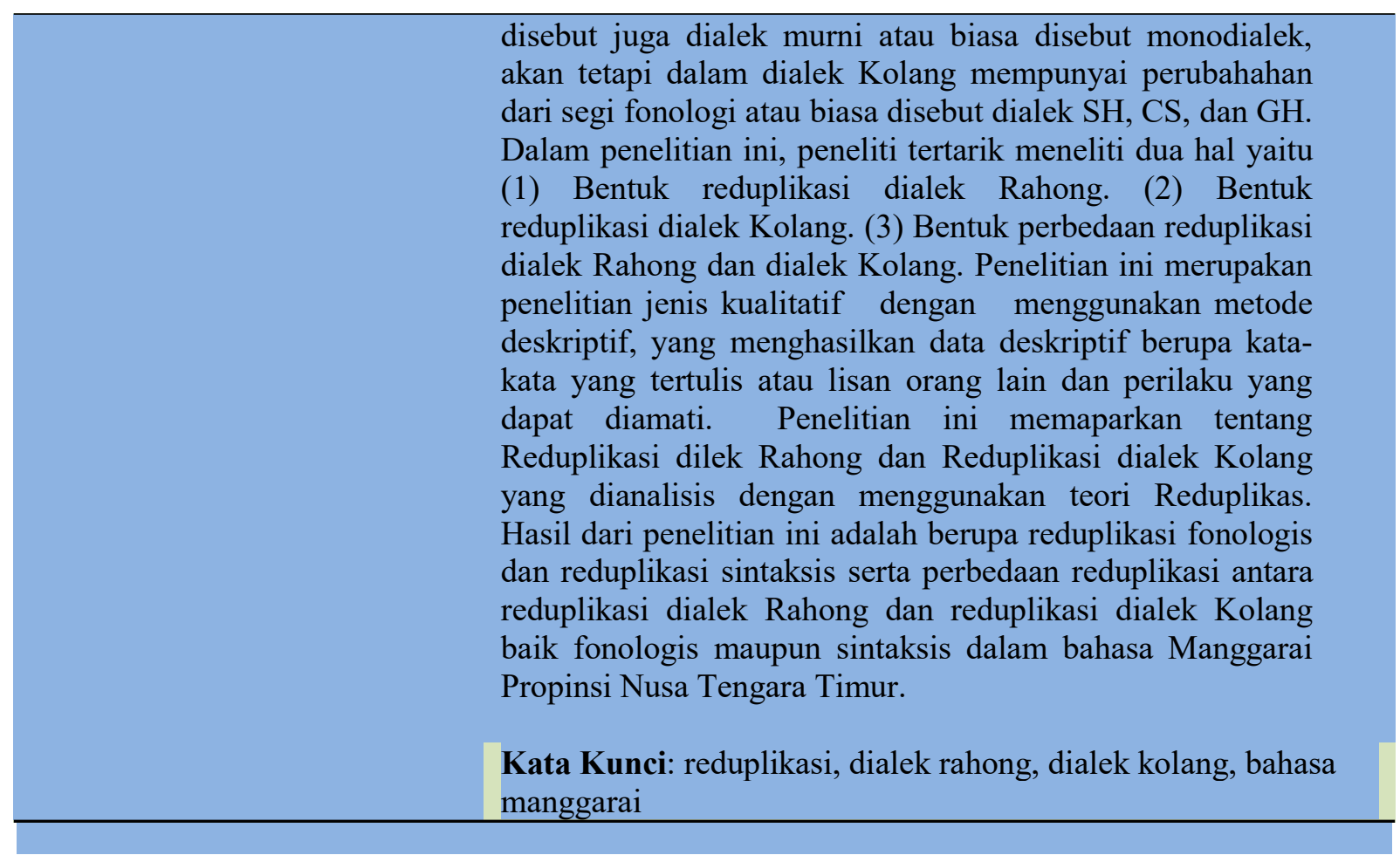

\section{PENDAHULUAN}

Bahasa adalah alat komunikasi atau alat interaksi yang hanya dimiliki oleh manusia. Bahasa merupakan suatu sistem komunikasi yang mempergunakan symbol-simbol vokal (bunyi ujaran) yang bersifat arbriter, yang dapat diperkuat dengan gerak gerik badaniah yang nyata. Bahasa juga sering disebut bersifat dinamis, artinya bahasa selalu berkembang, sejalan dengan perkembangan manusia sebagai pemakai bahasa. Bahasa bersifat produktif, artinya bahasa itu terus menghasilkan sesuatu meskipun unsur- unsurnya terbatas. Bersifat sistematis berarti bahasa tersusun menurut suatu pola dan bersifat sistemis berarti bahasa terdiri dari sub-subsistem. Selanjutnya, bahasa itu bermakna. Jadi, bahasa harus selalu dipelajari untuk menemukan makna yang tepat sesuai dengan perkembangan pemakai bahasa. Linguistik sebagai ilmu bahasa terdiri dari beberapa cabang, salah satunya yaitu morfologi. morfologi yaitu ilmu yang mempelajari tentang kata dan proses embentukannya. Proses morfologis bermacam-macam. Menurut Chaer (2008: 27), proses morfologi terdiri dari afiksasi, reduplikasi, komposisi, akronimisasi, dan proses konversi.

Penelitian ini terfokus pada proses reduplikasi. Reduplikasi adalah perulangan suatu bentuk dasar yang menghasilkan bentuk baru, yaitu kata ulang (Rohmadi, 2010: 95) Salah satu fungsi reduplikasi adalah mengubah bentuk tunggal menjadi bentuk jamak fungsi tersebut senada dengan bentuk fisik kata ulang. Hal inilah yang mempengaruhi pola sebagian besar pengguna bahasa dalam memaknai reduplikasi. Mereka memaknai semua kata ulang sebagai bentuk jamak dan atau sebagai suatu kegiatan yang dilakukan secara berulang-ulang.

Bahasa Indonesia di Indonesia yang amat luas wilayah pemakaianny dan bermacam ragam penuturnya, sehingga harus mengikuti perubahan yang dialami. Arah perubahan itu selalu tak terelakan karena siapapun tidak dapat mengubah bahasa secara berancana. Adanya faktor sosilal dan faktor-faktor situasional mempengaruhi pemakaian bahasa atau lebih tepatnya pemakaian Bahasa itu bersifat beragam (heterogen). Keanekaragaman bahasa nampak pemakaiannya baik secara individu maupun secara berkelompok. Ragam bahasa itu ditinjau dari sudut pandangan penutur dapat diperinci menurut patokan daerah, pendidikan, 
dan sikap penutur.

Bahasa daerah merupakan salah satu unsur kebudayaan daerah yang harus dilestarikan dan dikembangkan untuk mengembangkan fungsi kedaerahannya, karena bahasa daerah sangat berperan dalam memperkaya perbendaharaan bahasa Indonesia. Bahasa Manggarai salah satu bahasa daerah di kabupaten Manggrai yang dipelihara baik oleh masyarakat Manggarai. Bahasa Manggarai layaknya bahasa-bahasa yang lain tentunya memiliki unsur-unsur bahasa yang turut mengatur bahasa itu sendiri, seperti unsure fonologi, morfologi, sintaksis dan semantik.

P. Jilis Verheijen (1950), antropolog dan pakar linguistik adalah yang pertama kali membagi wilayah daerah bahasa Manggarai ke dalam 4 bagian: dialek barat, timur, tengah dan dialek SH. Di bagian barat ada dialek Kempo, Boleng, Matawae, Welak dan dialek Komodo di pulau Komodo. Bagian Manggarai tengah meliputi Rahong, Cibal dan Satar Mese menggunakan bahasa Manggarai "murni" dan dianggap sebagai monodialektis dengan aksen yang spesifikal sekali. Di bagian timur ditemukan dialek dan bahasa-bahasa Rongga, Mbaen, Bai'/Toe', Pae', Rembong dan Ning, masing-masing dengan spesifik yang memuat pengaruh besar dari bahasa-bahasa Flores Tengah, seperti Ngada, Nage Keo dan Lio. Dialek SH dan $\mathrm{CH}$ lebih mengacu kepada daerah-daerah Kolang, Pacar, Berit, Rego dan Nggalak, di mana huruf "S" dari bahasa Manggarai diucapkan sebagai "H". Misalnya: "salang" (jalan) diucapkan "halang", "cio" (kencing) diucapkan "sio". atau Semua bahasa dan dialek di atas memiliki struktur dan gramatika yang mirip dengan bahasa induk (Manggarai), meskipun banyak perbedaan dalam kosakata, lafal dan pengucapan.

Pengelompokan dialek tersebut sekaligus mengisyaratkan secara umum kelompok budaya di Manggarai yang erat kaitanya dengan corak kesatuan geologis, sebab kesatuan geologis yang besar di Manggarai adalah Wa'u (klen patrilineal) dan perkawinanpun patrilikal patrilokal, disinilah Bahasa dipelihara dan berkembang sampai sekarang secara turun temurun. Pada kali ini peneliti hanya mengangkat dua dialek diantaranya dilek barat yatu Kolang dan dialek tengah yaitu Rahong. Berbagai pertimbangan-pertimbangan yang mendasar alasan dalam penelitian ini, pertama alasan peneliti karena peneliti merasa bahwa reduplikasi dialek kolang itu sesuatu yang unik dalam pengucapan atau kalu dikaji perbedannya sangat jauh misalkan dalam dialek kata makan dialek dituis

"ghang" sedangkan dalam dialek Rahong kata makan ditulis "hang" karena dalam dialek Rahong menggunakan dialek murni sedangkan dialeh kolang menggunakan dialek gh, c, dan h. yang kedua di dalam masyarakat tidak lepas menggunakan reduplikasi dalam berkomunikasi antar masyarakat sehingga sangat penting untuk diteliti

Pentingnya pengkajian ini dapat ditinjau dari berbagai segi. Dari segi bahasa Manggarai, pengkajian ini dianggap sebagai suatu upaya penyelamatan data kebudayaan dan latar belakang sosial budaya yang dikuatirkan akan mengalami kepunahan. Dari segi bahasa Indonesia pengkajian ini sangat penting karena data kebahasaan Bahasa Manggarai ini mungkin dapat membantu memperkaya kata-kata dalam bahasa indonesia yang mungkin dapat dipergunakan sebagai sumber pembentukan istilah-istilah baru.

Pengkajian ini juga berfungsi sebagai pengembangan linguistik nusantara khususnya di NTT. Di samping itu, data tentang bahasa Mnnggarai tersebut dapat dipergunakan sebagai informasi bagi pemahaman kemestaan bahasa. Hal ini berarti bahwa, semakin banyak data bahasa yang dipergunakan dari pengkajian lapangan, semakin banyak pula kita peroleh sifat keharmonisan fenomena kebahasaan.

Sekiranya hal-hal di ataslah yang mendorong penulis untuk melakukan penelitian terhadap bentuk reduplikasi bahasa Manggarai barat dialeg kolang agar unsur- unsure tersebut tidak hilang atau punah.

Fransiskus Mariano Jer, dkk. Analisis Perbedaan Reduplikasi Dialek Rohing dan Dialek Kolang dalam Bahasa Manggarai Provinsi Nusa Tenggara Timur 


\section{METODE PENELITIAN}

Jenis penelitian deskriptif kualitatif yang digunakan pada penelitian ini dimaksud untuk memperoleh informasi mengenai bahasa tutur dialek Kolang dan dialek Rahong di Bangka Kiong dan di Bangka Ruang secara mendalam. Selain itu, dengan pendekatan kualitatif diharapkan dapat diungkapkan situasi yang dialami dalam kegunaan reduplikasi. Maka pendekatan kualitatif akan lebih mendorong pada pencapaian data yang bersifat lebih mendalam terutama dengan keterlibatan peneliti sendiri di lapangan. Dalam penelitian kualitatif, peneliti menjadi instrumen utama dalam mengumpulkan data yang dapat berhubungan langsung dengan instrument atau objek penelitian. Data yang dikumpulkan dari penelitian ini berupa bentuk reduplikasi dialeg Kolang dan dialek Rahong di Manggarai Nusa Tenggara Timur. Sumber data dalam penelitian ini adalah bahasa yaang digunakan oleh masyarakat daerah Kolang yaitu reduplikasi dialek Kolang. Masyarakat nantinya akan menceritakan tentang reduplikasi dialek Rahong dan dialek Kolang.

Sumber data dalam penelitian ini berwujud tuturan berupa dialek yang didapatkan penulis melalui masyarakat. Dialek itu merupakan hasil tuturan lisan masyarakat penutur dalam bahasa Manggarai yang mengandung kemampuan atau pengetahuan tentang bahasa Manggarai. Adapun kriteria dalam pemilihan informan dalam penelitian ini adalah sebagai berikut.

a. Berumur antara 20 s.d 50 tahun. Hal ini berdasarkan atas asumsi bahwa informan yang berumur antara 20 s.d 50 tahun memiliki kematangan dalam berbicara.

b. Informasi bersifat jujur. Hal ini dimaksudkan data yang diambil betul-betul alamiah

c. Tidak memiliki cacat wicara. Hal ini dapat memunculkan data yang tidak sesuai dengan keinginan peneliti

\section{HASIL DAN PEMBAHASAN}

Berdasarkan analisis data yang dilakukan oleh peneliti maka diperoleh beberapa jenis reduplikasi yaitu.

1. Reduplikasi Fonologis

Berdasarkan data temuan peneliti akan memdeskripsikan reduplikasi fonologis dialek Rahong sebagai berikut:

Tabel 1. Reduplikasi fonologis dialek Rahong

\begin{tabular}{ccc}
\hline No & & Reduplikasi \\
\cline { 2 - 3 } $\mathbf{1}$ & Dialeg Rahong & Arti \\
$\mathbf{2}$ & hole-hales & membalikan badan \\
$\mathbf{3}$ & cali celong & meminjam \\
$\mathbf{4}$ & cali-caluk & tertukar \\
$\mathbf{5}$ & cabi-cebong & memandikan \\
$\mathbf{6}$ & cari-curup & mengatakan \\
$\mathbf{7}$ & hang-hang & makanan \\
$\mathbf{8}$ & curup-curup & perkataan \\
\hline
\end{tabular}

42 Fransiskus Mariano Jer, dkk. Analisis Perbedaan Reduplikasi Dialek Rohing dan

Dialek Kolang dalam Bahasa Manggarai Provinsi Nusa Tenggara Timur 


\begin{tabular}{ccc}
\hline $\mathbf{9}$ & saung-haung & dedaunan \\
$\mathbf{1 0}$ & ces-ces & kedinginan \\
\hline
\end{tabular}

Berdasarkan data temuan peneliti akan memdeskripsikan reduplikasi fonologis dialek Kolang sebagai berikut:

Tabel 2 Reduplikasi fonologis dialek Kolang

\begin{tabular}{cll}
\hline No & \multicolumn{2}{c}{ Reduplikasi } \\
\cline { 2 - 3 } $\mathbf{1}$ & ghole-ghales & \multicolumn{1}{c}{ Arti } \\
$\mathbf{2}$ & sali-selong & membalikan badan \\
$\mathbf{3}$ & sali-saluki & meminjam \\
$\mathbf{4}$ & sabi-sebong & tertukar \\
$\mathbf{5}$ & Sari-surup & memandikan \\
$\mathbf{6}$ & ghang-ghang & mengatakan \\
$\mathbf{7}$ & Surup-surup & makanan \\
$\mathbf{8}$ & Suru-suru & perkataan \\
$\mathbf{9}$ & Haung-haung & menjemput \\
$\mathbf{1 0}$ & She-seh & dedaunan \\
\hline
\end{tabular}

Tabel di bawah ini peneliti akan membandingkan data reduplikasi fonoligis dialek Rahong dan data dialek Kolang dalam Bahasa Manggarai sebagai berikut:

Tabel 3. Perbedaan reduplikasi dialek Rahong dan dialek Kolang

\begin{tabular}{llll}
\hline & & \multicolumn{2}{c}{ Reduplikasi } \\
\cline { 2 - 4 } No & Dialeg Rahong & Dialek kolang & \multicolumn{1}{c}{ Arti } \\
$\mathbf{1}$ & hole-hales & ghole-ghales & membalikan badan \\
$\mathbf{2}$ & cali celong & sali-selong & meminjam \\
$\mathbf{3}$ & cali-caluk & sali-saluki & tertukar \\
$\mathbf{4}$ & cabi-cebong & sabi-sebong & memandikan \\
$\mathbf{5}$ & cari-curup & Sari-surup & mengatakan \\
$\mathbf{6}$ & hang-hang & ghang-ghang & makanan \\
$\mathbf{7}$ & curup-curup & Surup-surup & perkataan \\
$\mathbf{8}$ & curu-curu & Suru-suru & menjemput \\
$\mathbf{9}$ & saung-haung & Haung-haung & dedaunan \\
$\mathbf{1 0}$ & ces-ces & Seh-seh & kedinginan \\
\hline
\end{tabular}

2. Reduplikasi Sintaksis

Pada tabel berikut peneliti akan mendeskripsikan data reduplikasi sintaksis dialek Rahong dalam Bahasa Manggarai sebagai berikut:

Tabel 4. Reduplikasi Sintaksis dialek Rahong

\begin{tabular}{cll}
\hline & \multicolumn{2}{c}{ Reduplikasi } \\
\cline { 2 - 3 } No & \multicolumn{1}{c}{ Dialek Rahong } & \multicolumn{1}{c}{ Arti } \\
$\mathbf{1}$ & cei-cei ata main & siapa-sipa yang datang \\
$\mathbf{2}$ & cua-sua kat eme ata lako & dua-dua kalua mau pergi \\
\hline
\end{tabular}

Fransiskus Mariano Jer, dkk. Analisis Perbedaan Reduplikasi Dialek Rohing dan Dialek Kolang dalam Bahasa Manggarai Provinsi Nusa Tenggara Timur 


\begin{tabular}{|c|c|c|}
\hline 3 & campe-campe tau eme kerja & $\begin{array}{l}\text { kalau berkerja saling } \\
\text { membantu }\end{array}$ \\
\hline 4 & hia-hia taung ata tombo ne ngitu & $\begin{array}{l}\text { kamu selalu berbicara seperti } \\
\text { itu }\end{array}$ \\
\hline 5 & $\begin{array}{l}\text { hang-hang ne nggo kat ata mangan ta } \\
\text { kae }\end{array}$ & bang makan begini saja \\
\hline 6 & Cari-curup hau ta & kamu yang mengatakan \\
\hline 7 & naka cau-cau taung bola hitu & jangan kau pegang bola itu \\
\hline 8 & hia cambi-cembur kat one tiwu & dia menyembur saja ke kolam \\
\hline 9 & hau ata cali caluk taung sendal daku & $\begin{array}{l}\text { kamu yang selalu menukar } \\
\text { sandal saya }\end{array}$ \\
\hline 10 & de enu capi copel kaut hau bo $g$ & aduh nona mungkin ini ajalmu \\
\hline
\end{tabular}

Pada tabel berikut peneliti akan mndeskripsikan data reduplikasi sintaksis dailek Kolang dalam Bahasa Manggarai sebagai berikut.

Tabel 5. Reduplikasi Sintaksis dialek Kolang

\begin{tabular}{|c|c|c|}
\hline \multirow[t]{2}{*}{ No } & \multicolumn{2}{|c|}{ Reduplikasi } \\
\hline & Dialek Kolang & Arti \\
\hline 1 & sei-sei ata main & siapa-sipa yang datang \\
\hline 2 & hua-hua kat ata lako & dua-dua kalua mau pergi \\
\hline 3 & sampe-sampe tau eme kerja & kalau berkerja saling membantu \\
\hline 4 & ghia-ghia taung ata tombo ne ngitu & kamu selalu berbicara seperti itu \\
\hline 5 & $\begin{array}{l}\text { ghang-ghang ne nggo kat ata mangan } \\
\text { ta kae }\end{array}$ & bang makan begini saja \\
\hline 6 & sari-surup hau ta & kamu yang mengatakan \\
\hline 7 & neka sau-sau taung bola hitu & jangan kau pegang bola itu \\
\hline 8 & hia hambi-hembur kat one tiwu & dia menyembur saja ke kolam \\
\hline 9 & sei ata sali saluk taung sendal daku & $\begin{array}{l}\text { kamu yang selalu menukar sandal } \\
\text { saya }\end{array}$ \\
\hline 10 & de nana sapi sopel kaut hau bo g & aduh nona mungkin ini ajalmu \\
\hline
\end{tabular}

Pada Tabel di bawah ini peneliti akan membandigkan data reduplikasi sintaksis dialek Rahong dan data dialek Kolang dalam Bahasa Manggarai sebagai berikut:

Tabel 6 Perbedaan reduplikasi dialek Kolang dan dialek Rahong

\begin{tabular}{|c|c|c|c|}
\hline \multirow{2}{*}{ No } & \multicolumn{3}{|c|}{ Reduplikasi } \\
\hline & Dialeg Rahong & Dialek kolang & Arti \\
\hline 1 & cei-cei ata main & sei-sei ata main & siapa-sipa yang datang \\
\hline 2 & cua-sua kat eme lako & hua-hua kat ata lako & $\begin{array}{l}\text { dua-dua kalua mau } \\
\text { pergi }\end{array}$ \\
\hline 3 & campe-campe tau eme kerja & $\begin{array}{l}\text { sampe-sampe tau eme } \\
\text { kerja }\end{array}$ & $\begin{array}{l}\text { kalau berkerja saling } \\
\text { membantu }\end{array}$ \\
\hline 4 & $\begin{array}{l}\text { hia-hia taung ata tombo ne } \\
\text { ngitu }\end{array}$ & $\begin{array}{l}\text { hia-ghia taung ata } \\
\text { tombo ne ngitu }\end{array}$ & $\begin{array}{l}\text { dia selalu berbicara } \\
\text { seperti itu }\end{array}$ \\
\hline
\end{tabular}

44 Fransiskus Mariano Jer, dkk. Analisis Perbedaan Reduplikasi Dialek Rohing dan Dialek Kolang dalam Bahasa Manggarai Provinsi Nusa Tenggara Timur 


\begin{tabular}{|c|c|c|c|}
\hline 5 & $\begin{array}{l}\text { hang-hang ne nggo kat ata } \\
\text { mangan ta kae }\end{array}$ & $\begin{array}{l}\text { ghang-ghang ne nggo } \\
\text { kat ata mangan ta kae }\end{array}$ & $\begin{array}{l}\text { bang makan begini saja } \\
\text { apa adanya }\end{array}$ \\
\hline 6 & Cari-curup hau ta & sari-surup hau ta & kamu yang mengatakan \\
\hline 7 & $\begin{array}{l}\text { naka cau-cau taung bola } \\
\text { hitu }\end{array}$ & $\begin{array}{l}\text { neka sau-sau taung } \\
\text { bola hitu }\end{array}$ & $\begin{array}{l}\text { jangan kau pegang terus } \\
\text { bola itu }\end{array}$ \\
\hline 8 & $\begin{array}{l}\text { hia cambi-cembur kat one } \\
\text { tiwu }\end{array}$ & $\begin{array}{l}\text { hia hambi-hembur kat } \\
\text { one tiwu }\end{array}$ & $\begin{array}{l}\text { dia menyembur saja ke } \\
\text { kolam }\end{array}$ \\
\hline 9 & $\begin{array}{l}\text { hau ata cali caluk taung } \\
\text { sendal daku }\end{array}$ & $\begin{array}{l}\text { sei ata sali saluk taung } \\
\text { sendal daku }\end{array}$ & $\begin{array}{l}\text { kamu yang selalu } \\
\text { menukar sandal saya }\end{array}$ \\
\hline 10 & $\begin{array}{l}\text { enu capi copel kaut hau bo } \\
\text { g }\end{array}$ & $\begin{array}{l}\text { de nana sapi sopel kaut } \\
\text { hau bo g }\end{array}$ & $\begin{array}{l}\text { nona mungkin ini } \\
\text { ajalmu }\end{array}$ \\
\hline
\end{tabular}

Dalam penelitian ini, tidak menemukan reduplikasi morfologis dan semantis, hanya ditemukan reduplikasi fonologi dan sintaksis. Adapun perbedaan reduplikasi Dialek Rahong (DR) dan Dialek Kolang (DK) dalam bahasa Manggarai Nusa Tenggara Timur yang memiliki proses morfologi dan sintaksis antara lain sebagai berikut:

\section{Analisis data fonologis bentuk reduplikasi dialek Rahong}

a. Reduplikasi sebagian bentuk dasar (dikopi sebagian bentuk dasar). Silabel yang dikopi dari si label kedua bentuk dasar seperti pada data berikut

1) Data 1 /DR hole-hales yang berarti membalikkan badan scara terus

menerus. kata dasar holes yang berarti membalikkan badan ditambah dengan hales menjadi membalikkan badan secara terus menerus

holes $\rightarrow$ membalikan badan

holes + hales $\rightarrow$ membalikan bada secara terus menerus

2) Data $2 /$ DR cali-caluk yang berarti tukar-menukar scara terus menerus. kata dasar caluk yang berarti tukar ditambah dengan hales menjadi tukar-menukar scara terus menerus caluk $\rightarrow$ tukar

cali + caluk $\rightarrow$ tukar-menukar scara terus menerus

3) Data $3 / \mathrm{DR}$ cali-celong yang berarti meinjam terus-menerus. kata dasar celong yang berarti meminjam ditambah dengan cali menjadi meinjam terus-menerus

celong: meminjam

cali + celong $\rightarrow$ meminjam terus-menerus

4) Data $4 / \mathrm{DR}$ cabi-cebong yang berarti mandi terus menerus. kata dasar cebong yang berarti mandi ditambah dengan cabi menjadi mandi terus menerus

cebong: mandi

cabi-cebong $\rightarrow$ mendi terus

5) Data $5 / \mathrm{DR}$ cari-curup yang berarti mengatakan terus menerus. kata dasar curup yang berarti mengatakan ditambah dengan cari menjadi mengatakan terus menerus curup: mengatakan cari + curup $\rightarrow$ mengatakan terus

b. reduplikasi bentuk pengulangan secara utuh dan dasarnya tidak berstatus sebagai akar seperti pada data berikut

1) Data $6 / \mathrm{DR}$ hang-hang yang berarti mkan-makan kata dasar makan ditambah dengan

Fransiskus Mariano Jer, dkk. Analisis Perbedaan Reduplikasi Dialek Rohing dan 
silabe makan menjadi makan-makan

hang: makan

hang + hang $\rightarrow$ makan-makan

2) Data 7/DR curup-curup yang berarti mengatakan berkali-kali kata dasar curup ditambah dengan silabe cari menjadi mengatakan berkali-kali

curup: mengatakan

curup + curup $\rightarrow$ mengatakan berkali-kali

3) Data $8 /$ DR curu-curu yang berarti jemput-jemput kata dasar jemput ditambah dengan silabe curu menjadi jemput-jemput

curu-curu

curu: jemput

curu + curu $\rightarrow$ jemput-jemput

4) Data $9 /$ DR saung-saung yang berarti daun-daun kata dasar daun ditambah dengan silabe daun menjadi daun-daun

saung: daun

saung + saung $\rightarrow$ daun-daun

5) Data $10 / \mathrm{DR}$ ces-ces yang berarti dingin-dingin kata dasar ces ditambah dengan silabe ces menjadi ces-ces

ces + ces

ces: dingin

ces + ces $\rightarrow$ dingin-dingin

\section{Analisis data fonologis bentuk reduplikasi dialek Kolang}

a. Reduplikasi sebagian bentuk dasar (dikopi sebagian bentuk dasar). Silabel yang dikopi dari silabel kedua bentuk dasar seperti pada data berikut

1) Data 1 /DK hole-haleh yang berarti membalikkan badan scara terus menerus. kata dasar holes yang berarti membalikkan badan ditambah dengan haleh menjadi membalikkan badan secara terus menerus

holeh $\rightarrow$ membalikan badan

holeh + haleh $\rightarrow$ membalikan bada secara terus menerus

2) Data 2 /DK sali-saluk yang berarti menukar secara terus menerus. kata dasar salik yang berarti menukar ditambah dengan saluk menjadi tukar menukar secara terus menerus

saluk $\rightarrow$ menukar

sali + saluk $\rightarrow$ tukar-menukar secara terus menerus

3) Data 3 /DK sali-selong yang berarti dipinjam terus-menerus. kata dasar selong yang berarti meinjam ditambah dengan cali menjadi meminjam berkali-kali

selong: meminjam

sali + selong $\rightarrow$ meminjam terus-menerus

4) Data $4 / \mathrm{DK}$ sabi-sebong yang berarti mandi terus menerus. kata dasar sebong yang berarti mandi ditambah dengan silabe cabi menjadi mandi terus menerus

sebong: mandi

sabi-sebong $\rightarrow$ mendi terus menerus

5) Data $5 / \mathrm{DK}$ sari-surup yang berarti mengatakan terus menerus. kata dasar surup yang berarti mengatakan ditambah dengan cari menjadi mengatakan terus menerus surup: mengatakan 
sari + surup $\rightarrow$ mengatakan terus terus

b. Reduplikasi bentuk pengulangan secara utuh dan dasarnya tidak berstatus sebagai akar seperti pada data berikut

1) Data $6 / \mathrm{DK}$ ghang-ghang yang berarti mkan-makan kata dasar makan ditambah dengan silabe makan menjadi makan-makan

ghang: makan

ghang + ghang $\rightarrow$ makan makan

2) Data $7 / \mathrm{DK}$ surup-surup yang berarti mengatakan berkali-kali kata dasar surup ditambah dengan silabe sari menjadi mengatakan berkali-kali

surup: mengatakan

suri + surup $\rightarrow$ mengatakan berkali-kali

3) Data $8 /$ DK suru-suru yang berarti jemput-jemput kata dasar suru ditambah dengan silabe suru menjadi jemput-jemput

Jemput

suru + suru $\rightarrow$ jemput-jemput

4) Data 9 /DK haung-haung yang berarti daun-daun kata dasar haung

5) ditambah dengan silabe haung menjadi daun-daun

haung: daun

haung + haung $\rightarrow$ daun-daun

6) Data $10 / \mathrm{DK}$ she-seh yang berarti dingin-dingin kata dasar ces ditambah dengan silabe seh menjadi she-she

seh + she

she: dingin

she + seh $\rightarrow$ dingin-dingin

3. Analisis perbedaan data fonologis reduplikasi dialek Rahong dan dialek Kolan

a. Data $1 / \mathrm{DR}$ dan Data $1 / \mathrm{DK}$

Terdapat reduplikasi hole-haleh yang berarti membalikan badan pada dialek Rahong dan pada dialek Kolang kata ghole-ghaleh juga berarti membalikan badan. Pada kata holehales dan ghole-ghaleh terdapat perbedaan fonem yaitu $/ \mathrm{h} / \mathrm{dan} / \mathrm{gh} /$.

b. Data 2 /DR dan Data $2 / \mathrm{DK}$

Pada dialek Rahong reduplikasi cali-celong yang berarti meminjam dan dialek Kolang reduplikasi sali-selong juga berarti meminjam. Pada reduplikasi cali-celong dan saliselong terdapat perbedaan fonem yaitu $/ \mathrm{c} / \mathrm{dan} / \mathrm{s} /$.

c. Data 3 /DR dan Data 3 /DK

Pada reduplikasi cali-caluk dan sali-saluk yang berarti memegang. Reduplikasi cali-caluk berasal dari dialek Rahong sedangkan, reduplikasi sali-saluk berasal dari dialek Kolang. Pada reduplikasi cali-caluk dan sali-saluk terdapat perbedaan fonem yaitu $/ \mathrm{c} / \mathrm{dan} / \mathrm{s} /$.

d. Data 4 /DR dan Data 4/DK

Pada reduplikasi cambi-cembur dan sambi-sembur yang berarti menyembur. Reduplikasi cambi-cembur berasal dari dialek Rahong sedangkan, reduplikasi sambi-sembur berasal dari dialek Kolang. Pada reduplikasi cambi-cembur dan sambi-sembur terdapat perbedaan fonem yaitu $/ c /$ dan $/ s /$.

Fransiskus Mariano Jer, dkk. Analisis Perbedaan Reduplikasi Dialek Rohing dan

Dialek Kolang dalam Bahasa Manggarai Provinsi Nusa Tenggara Timur 
e. Data 6/DR dan Data $6 / \mathrm{DK}$

Terdapat reduplikasi cabi-cebong berarti memandi pada dialek Rahong

dan pada dialek Kolang kata sabi-sebong juga berarti memandi. Pada reduplikasi cabicebong dan sabi-sebong terdapat perbedaan fonem yaitu $/ c /$ dan $/ s /$.

f. Data $1 / \mathrm{DR}$ dan Data $1 / \mathrm{DK}$

Pada reduplikasi hang-hang dan ghang-ghang yang berarti makan-makan. Reduplikasi hang-hang berasal dari dialek Rahong sedangkan, reduplikasi ghang-ghang berasal dari dialek Kolang. Pada reduplikasi hang-hang dan ghang-ghang terdapat perbedaan fonem yaitu $/ h /$ dan $/ g h /$.

g. Data $9 / \mathrm{DR}$ dan Data $9 / \mathrm{DK}$

Terdapat reduplikasi curup-curup yang berarti perkataan pada dialek Rahong dan pada dialek Kolang kata surup-surup juga berarti perkataan. Pada kata curup-curup dan surupsurup terdapat perbedaan fonem yaitu $/ c /$ dan $/ s /$.

h. Data $8 /$ DR dan Data $8 / \mathrm{DK}$

Terdapat reduplikasi curu-curu yang berarti menjemput pada dialek Rahong dan pada dialek Kolang kata suru-suru juga berarti menjemput. Pada kata curu-curu dan suru-suru terdapat perbedaan fonem yaitu $/ c /$ dan $/ s /$.

i. Data 9/DR dan Data 9/DK

Terdapat reduplikasi saung-haung yang berarti menjemput pada dialek Rahong dan pada dialek Kolang kata haung-haung juga berarti menjemput. Pada kata curu-curu dan surusuru terdapat perbedaan fonem yaitu $/ s /$ dan $/ \mathrm{h} /$.

j. Data $10 / \mathrm{DR}$ dan Data 10/DK

Pada reduplikasi ces-ces dalam dialek rahong yang berarti kedinginan sedang kan pada reduplikasi dialek Kolang reduplijasi seh-seh yang berarti kedinganan juga. Pada kata ces-ces dan seh-seh terdapat perbedaan fonem awal dan akhir yaitu /c/ dan /s, h/.

\section{Analisis perbedaan data sintaksis reduplikasi dialek Rahong dan dialek Kolang}

a. Data $1 / \mathrm{DR}$ dan Data $1 / \mathrm{DK}$

Data kalimat cei-cei ata main pada dialek Rahong yang berarti siapa-siapa yang datang dan pada kalimat sei-sei ata main mempunyai arti yang sama siapa- siapa yang datang. Pada kedua reduplikasi cei-cei dan sei-sei terdapat perbedaan fonem yaitu $/ \mathrm{c} / \mathrm{dan} / \mathrm{s} /$

b. Data 2/DR dan Data 2/DK

Terdapat reduplikasi pada kalimat cua-sua kat eme lako yang berarti dua-dua kalau mau pergi dialek Rahong dan pada dialek Kolang pada hua-hua kat eme lako juga berarti perkataan. Pada reduplikasi sua-sua dan hua-hua terdapat perbedaan fonem yaitu $/ \mathrm{s} / \mathrm{dan}$ $/ h / /$.

c. Data $3 / \mathrm{DR}$ dan Data 3/DK

Terdapat reduplikasi pada kalimat campe-campe tau eme kerja yang berarti kalau berkerja saling membantu pada dialek Rahong, dan pada dialek Kolang sampe-sampe tau eme kerja juga berarti kalau berkerja saling membantu. Pada reduplikasi campe-campe dan sampe-sampe terdapat perbedaan fonem yaitu /c/ dan $/ s / /$.

d. Data 4 /DR dan Data 4 /DK

Terdapat reduplikasi pada kalimat hia-hia taung ata tombo ne ngitu yang berarti dia selalu berbicara seperti itu pada dialek Rahong, dan pada dialek Kolang ghia-ghia taung ata tombo ne ngitu juga berarti dia selalu berbicara seperti itu. Pada reduplikasi hia-hia dan ghia-ghia terdapat perbedaan fonem yaitu $/ \mathrm{h} / \mathrm{dan} / \mathrm{gh} /$.

e. Data 5/DR dan Data 5/DK 
Terdapat reduplikasi pada kalimat hang-hang ne nggo kat ata mangan ta kae yang berarti bang makan begini saja apa adanya pada dialek Rahong, dan pada dialek Kolang ghangghang ne nggo kat ata mangan ta kae berarti bang makan begini saja apa adanya. Pada reduplikasi hang-hang dan ghang-ghang terdapat perbedaan fonem yaitu $/ \mathrm{h} / \mathrm{dan} / g h /$.

f. Data $6 /$ DR dan Data $6 / \mathrm{DK}$

Terdapat reduplikasi pada kalimat cari-curup hau ta yang berarti kamu yang mengatakan pada dialek Rahong, dan pada dialek Kolang sari-surup hau ta berarti kamu yang mengatakan. Pada reduplikasi hang-hang dan ghang-ghang terdapat perbedaan fonem yaitu $/ \mathrm{c} / \mathrm{dan} / s /$.

g. Data $5 / \mathrm{DR}$ dan Data $5 / \mathrm{DK}$

Terdapat reduplikasi pada kalimat hia cambi-cembur kat one tiwu yang dia menyembur saja ke kolam pada dialek Rahong, dan pada dialek Kolang hia hambi-hembur kat one tiwu berarti jangan dia menyembur saja ke kolam. Pada reduplikasi cambi-cembur dan sambi-sembur terdapat perbedaan fonem yaitu $/ \mathrm{c} / \mathrm{dan} / \mathrm{s} /$.

h. Data 5 /DR dan Data 5 /DK

Terdapat reduplikasi pada kalimat hia cambi-cembur kat one tiwu yang dia menyembur saja ke kolam pada dialek Rahong, dan pada dialek Kolang hia hambi-hembur kat one tiwu berarti jangan dia menyembur saja ke kolam. Pada reduplikasi cambi-cembur dan sambi-sembur terdapat perbedaan fonem yaitu $/ \mathrm{c} / \mathrm{dan} / \mathrm{s} /$.

i. $\quad$ Data 5 /DR dan Data 5 /DK।

Terdapat reduplikasi pada kalimat hau ata cali caluk taung sendal daku yang berarti kamu yang selalu menukar sandal saya pada dialek Rahong, dan pada dialek Kolang sei ata sali saluk taung sendal daku berarti kamu yang selalu menukar sandal saya. Pada reduplikasi cali caluk dan sali saluk terdapat perbedaan fonem yaitu /c/ dan $/ s /$.

j. $\quad$ Data 5 /DR dan Data 5 /DK

Terdapat reduplikasi pada kalimat enu capi copel kaut hau bo g yang berarti nona mungkin ini ajalmu pada dialek Rahong, dan pada dialek Kolang Nana sapi sopel kaut hau bo g berarti nona mungkin ini ajalmu. Pada reduplikasi capi copel dan capi copel terdapat perbedaan fonem yaitu $/ \mathrm{c} /$ dan $/ s /$.

Berdasarkan data yang sudah dianalisis di atas hasil penelitian sebagai berikut 1) berupa bentuk reduplikasi dialek Rahong dan Dialek Kolang, 2) berupa redupliksi fonologis dialek Rahong dan Dialek Kolang, 3) berupa reduplikasi sintaksis dialek Rahong dan Dialek Kolang. Reduplikasi fonologis dialek Rahong mempunyai dua bentuk yaitu bentuk dasar dan bentuk berubah bunyi, sedangkan redupikasi dialek Kolang bentuknya sama persis dengan reduplikasi dialek Rahong hanya yang membedakan adalah dari segi pelafalan atau bunyinya saja.

Reduplikasi bentuk sintaksis yang di temukan tidak berbeda jauh dengan bentuk fonologis hanya yang membedakkan dari bentuk kata dan bentuk kalimat. Pada dialek Kolang sering disebut juga dialek $\mathrm{SH}, \mathrm{CS}$, dan GH dikarenakan pada dialek ini mempunyai perubahan $/ \mathrm{c} /, / \mathrm{s} /$, dan $/ \mathrm{gh} /$. Dalam perbandingannya pada fonem c dalam dialek rahong menjadi fonem s dalam dialek Kolang, fonem s dalam dialek Rahong menjadi fonem $\mathrm{h}$ dalam dialek Kolang dan pada fonem g pada dialek Rahong menjadi fonem gh pada dialek Kolang. Meskipun dari segi unsur fonologis dan sintsksis kedua dialek ini berbeda, namun maknanya sama persis dikarenakan sama-sama menggunakan bahasa manggarai. Hanya saja dialek rahong menggunakan dialek murni dan dianggap sebagai monodialek sedangkan dialek

Fransiskus Mariano Jer, dkk. Analisis Perbedaan Reduplikasi Dialek Rohing dan 
Kolang menggunakan dialek $\mathrm{SH}, \mathrm{CS}$, dan $\mathrm{GH}$

Seperti ditegaskan oleh Kridalakasana secara umum mengelompokkan reduplikasi atau pengulangan menjadi tiga kelompok besar, yaitu: reduplikasi fonologis, reduplikasi morfemis, dan reduplikasi sintaktis.

\section{KESIMPULAN}

Adapun simpulan yang dimaksud adalah sebagai berikut:

1. Dalam dialek Rahong dan dialek Kolang terdapat dua jenis reduplikasi yaitu reduplikasi fonologis dan reduplikasi sintaksis

2. Dalam reduplikasi fonologis maupun sintaksis hanya memiliki dua jenis tipe yaiti tipe pengulangan utuh dan tipe berubah bunyi

3. Reduplikasi dialek Rahong dan dialek Kolang terjadi perbedaan pada segi fonem sebagai berikut:

a. Reduplikasi dialek rahong terdapat fonrm yaitu Fonem /h/, /c/, dan /s/

b. Reduplikasi dialek Kolang terdapat fonrm yaitu Fonem /gh/, /s/, dan /sh/

Jadi, letak perbedaan reduplikasi antara dialek Rahong dan dialek Kolang yang ada dalam Bahasa Manggarai terletak pada fonem /h/, /c/, /s/, /gh/, dan /sh/.

\section{RUJUKAN}

Chaer, Abdul. 2010. Sosiolinguistik. Jakarta: Rineka , Abdul. 2015. Sosiolinguistik. Jakarta: Rineka

Cipta Chaer, Abdul. 2008. Morfologi Bahasa Indonesia: Pendekatan Proses. Jakarta: Rineka Cipta.

Congka sae (2010 11 Agustus) Dialek Manus/Toe' Di Manggarai Timur

Djajasudarma. 1993. "Semantik I Pengantar Kearah Ilmu Makna". Jakarta. PT ERESCO Anggota IKAPI

Finosa, Laminudin.2001. komposisi Bahasa Indonesia. Jakarta: Diksi Insan Mulia.

Hadari, Nawawi. (2007). Metode Penelitian Bidang Sosial. Yogyakarta: Gajah Mada University Press

Harimurti, Kridalaksan.1989. Pembentukan kata dalam bahasa Indonesia. Jakarta: Gramedia Pustaka Utama.

J.W.M. verhaar.1990. Pengantar linguistik jilid I. Yogyakarta: Gadjah Mada University.

Keraf, Gorys. 2004.Komposisi Sebuah Pengantar Kemahiran Bahasa. Flores: Nusa Indah.

Kiki (2008, 4 Juli). Mengenai dan Ragam Bahasa Indonesia h

Mahsun. 2005. Metode Penelitian Kuantitatif. Jakarta: Rajagrafindo Persada.

Ramlan, M. 1979. Morfologi: Suatu Tinjauan Deskriptif. Yogyakarta: U.P. Karyono.

Rohmadi, Muhammad dkk. 2010. Morfologi: Telaah Morfem dan Kata. Surakarta: Yuma Pustaka.

Rubianto, Rubianto. 2013. Penelitian Pendidikan. Surakarta: BP- FKIP UMS.

Siany dkk (2009). Khazanah Antropologi 1: Untuk Kelas XI SMA dan MA, Jakarta: Depdiknas

Simatupang. 1983. Reduplikasi morfemis bahasa Indonesia. Jakarta: Djambatan.

William dll. 2003. Morphology: the analysis of word structure. New York. 